\title{
Social security reforms in China: issues and prospects
}

Joe C. B. Leung (Dr.)

Running title: Social security reforms in China

Key words: social security, social assistance, unemployment insurance, unemployment, pensions, state-owned enterprises

Accepted for publication August 29, 2002

\author{
Correspondence to: \\ Dr. Joe C. B. Leung \\ Department of Social Work and Social Administration \\ The University of Hong Kong \\ E-mail: joe-leung@hku.hk
}




\section{Introduction}

The phenomenal success of China's market-oriented economic reforms since the 1980s has been accompanied by a wide array of social problems. Moreover, economic reforms have rendered the traditional work unit-based social security system increasingly inadequate and inefficient. For two decades the Chinese government has been trying to develop a more pluralistic, effective, and affordable social security system that will be compatible with both a thriving market economy and a flagging socialist political structure. Social security reform centers on the establishment of partially funded systems in retirement, unemployment, and medical insurance, moving away from the current pay-as-you-go systems, and the development of a basic social assistance program covering all urban residents. While the emerging system is still struggling with a variety of transitional operational problems, the entry of China into the WTO is looming as a formidable challenge to this social security system. Indeed, an effective social security system would not only facilitate economic reforms by promoting productivity, but also enhance social stability through the mitigation of social tensions and conflicts (Ministry of Labor and Social Security, 1999). This presentation outlines the background and recent reforms of the social security system undertaken by the Chinese government. It will focus on the retirement and unemployment insurance schemes, as well as the social assistance program.

\section{Socio-economic transformation}

Over the past two decades, China has become one of the fastest growing economies in the world. Between 1978 and 1999, China’s GDP grew at an average of almost 10\% a year. China in fact has enjoyed almost uninterrupted economic growth since the initiation of the market reforms in the 1980s. Currently, China is the sixth largest economy in the world and ninth in terms of volume of trade (China Daily, March 6, 2001; People’s Daily, January 1, 2002). While the 
world economy has undergone a dramatic slow-down and China's export to the US is expected to show a significant reduction, China is still expected to enjoy an average annual growth rate of 7-8\% in the coming decade (Beijing Review, 38, 2001).

According to the 1998 World Bank Report, the per capita GDP of China has reached US\$860 (China Daily, August 13, 2001). China now ranks for the first time as a lower-middle-income economy (World Bank, 2001: 271). China has led the developing world in the use of direct foreign investment in the last decade, and the foreign exchange reserve of China has been ranked third in the world after Japan and the European Union (People's Daily, November 7, 2001). Nevertheless, outstanding foreign debts at the end of June 2001 rose to US\$170.41 billion, as compared with US\$135.73 billion at the end of 2000 . Since 1979, the central government, with the exception of slight surpluses in 1981 and 1985, has run into continuous budget deficits. The mounting deficits of 170 billion yuan in 1998 and 250 billion yuan in 1999 were unprecedented (US\$1 = 8.3 yuan) (China Internet Information Center, www.china.org.cn). Furthermore, the fiscal revenues of the central government have declined over the years, mainly due to the non-performance of the state sector, preferential policies to attract foreign investments, and inability to tackle tax evasion. In fact, the relative weight of the state's fiscal revenues as a percentage of the GNP continues to decline all the time - not even one half of the level of a typical industrialized country with a market economy (Wang \& Hu, 2001). Overall speaking, despite the sustained and fast development in recent years, China's current economic development level is only equivalent to that of Japan’s in the early 1960s (People’s Daily, January 16, 2002).

In terms of Human Development Index (covering life expectancy, GDP per head and educational attainment), produced by the United Nations Development Program and covering a total of 162 countries, China was ranked 87 in 2001 (ranked $111^{\text {th }}$ among 174 countries in 1995), despite its per capita GDP was ranked only $94^{\text {th }}$ (The Economist, July 14, 2001: 98). Between 1990 and 1999, the average wages, incomes of urban residents and peasants, have increased 3-4 
times (Ministry of Civil Affairs, 2001: 81; State Statistical Bureau, 2001: 144). As a miracle, China has reduced its rural poverty-stricken population from 250 million in 1978 to only 30 million in 2000 (poverty line in 2000 was defined as the annual per capita income of 625 yuan) (China Internet Information Center, www.China.org.cn). According to the figures compiled by the State Statistical Bureau, there were 14.8 million urban residents, representing $3.8 \%$ of the urban population, living below the poverty line, with an average per capita annual income of 2,310 yuan (China Civil Affairs, 2001: 18-21).

Beginning in the 1980s, market-oriented economic reforms focused on the gradual liberalization of the economic structure and the enlargement of the production and management autonomy of state-owned enterprises (SOEs). With the introduction of a more pluralistic economy, the state sector has ceased to be the major economic sector. In 1999, the state sector only contributed to about 26.1\% of the Gross Industrial Output Value, down from 76\% in 1980. In terms of employment, only $40.8 \%$ of the urban employees worked in the state sector in 1999 , as compared with 76.2\% in 1980 (State Statistical Bureau, 2000: 409, 118-9). (See Table 1.) Now collectively-owned enterprises (COEs) (mainly owned by township governments), privately-owned enterprises (owned by individuals and foreign capitals) become the engines of economic growth. In fact, the Chinese Communist Party has endorsed that non-state-owned enterprises are an integral part of the socialist market economy in the $15^{\text {th }}$ Party Congress in 1997. The Chinese Constitution was amended in 1999 to recognize that privately owned enterprises can have equal status and treatment as SOEs (The Economist, August 11, 2001: 23). The Law on Enterprises Funded Exclusively by Individuals, which came into effect in 2000, gives further push to private businesses.

Under an increasingly market-oriented, competitive, and globalized economy, the performance of SOEs was disappointing. Many of them are debt-riddened with mounting losses. From 1998 to 2000, state enterprises had laid off a total of 23 million employees (People's Daily, September 24, 2001). Looking into the future, the Chinese economy will become 
increasingly 'privatized,' with the collectives and the private sectors making the major share of the economy and providing most of the new jobs.

Economic reforms have also transformed the industrial structure. In terms of the production value, primary industry (farming and agriculture) has continued to decline in importance. In 2000, it constituted only $15.9 \%$ of the total output value, down from $20.1 \%$ in 1980 (State Statistical Bureau, 2001: 53). Despite the significant improvements already made by the tertiary industry, its contribution to the total output value was only $33.2 \%$ in 2000 , as compare with $21.4 \%$ in 1980 (see Table 2). It is envisaged that output value of the tertiary industry will increase to $36 \%$ by 2005 , while the primary industry will continue to drop to $13 \%$ (People's Daily, October 19, 2001). However, primary industry still employed half of the workforce, declining from almost 70\% in 1980 (see Table 3). Noteworthy is the fact that township enterprises have employed some 127 million peasants, and in a way keep these peasants from moving into cities for jobs. The urbanization rate in 1999 was only 31\%, as compared with 19\% in 1980 (see Table 4). Taken together, in China, despite all the achievement, the majority of the citizens live in the rural areas and engage in the agricultural economy.

A formidable problem facing the Chinese government is soaring unemployment (see Table 5). The pressures to create jobs are due to:

- Increase in labor supply: Mainly due to relatively high birth rates in the early 1980s, there will be an average of 10 million young people each year entering into the working age in the coming five years. The proportion of the working population will reach a peak in 2010, before making a gradual decline.

- Continuous massive layoffs from SOEs: The situation is expected to further deteriorate after the entry of China into the World Trade Oorganization (WTO).

- Increased rural-urban migration: More peasants are moving into cities for jobs because of the declining agricultural sector, aggravated further by the entry of China into the WTO. 
- Slow down of economic growth: Less number of jobs can be created.

Together with factors such as the high employment rate of retirees and women, the issue of providing jobs and assistance to the unemployed has become one of the most urgent concerns of the Chinese government in recent years.

With the continuous low birth rates and natural growth rates for more than two decades (birth rate was 15.2 per 1000 population, death rate 6.5 per 1000 population, and natural growth rate 8.8 per 1000 population in 1999), the proportion of children (aged 0-14) in the national population declined from 33.6\% in 1982 to only 22.9\% in 2000 (see Table 6). According to the 2000 census, the population of Mainland China was 1.266 billion people. As compared with the population in the last census in 1990, the average annual increase was $1.07 \%$, representing 12.79 million people (People’s Daily, March 29, 2001). However, natural growth rates vary from -1.1 per 1000 population in Shanghai, 0.9 per 1000 population in Beijing, and 3.56 per 1000 population in Jiangsu, to 15.8 per 1000 population in Tibet, 14.2 per 1000 population in Guizhou, and 13.9 per 1000 population in Qinghai (State Statistical Bureau, 2000: 96). According to the $10^{\text {th }}$ Five-year Plan on Economic and Social Development (2001-2005), the government pledged to maintain the national population size within 1.33 billion people, the net increases of the population within 56 million, and the natural growth rate below 9 per 1000 population in the coming five years (People's Daily, August 10, 2001). Meanwhile the government will enact the first Law on Family Planning and Population in 2002. Accordingly, a couple is encouraged to bear one child, and can have a second child only in exceptional circumstances (People’s Daily, December 12, 2001).

\section{Table 6 in about here}

One of the consequences of the active population control policy in China is the rapid increase in the proportion of the elderly population. The proportion of the older people (aged 65 
or over) in the national population surged from $4.9 \%$ in 1982 to $5.6 \%$ in 1990 , and further to $6.96 \%$ in 2000 , representing 88.11 million people. Noteworthy is the fact that the regional variation in the proportion of aging population is substantial. In general, coastal provinces and cities (Shanghai, 13.8\%; Jiangsu, 9.8\%; Zhejiang, 9.5\%) have much higher proportion of the aging population than those in the western provinces (Tibet, 4.1\%; Ningxia, 4.5\%; and Xinjiang, 4.7\%). (State Statistical Bureau, 2001: 102). In terms of the aged dependency ratio (the proportion of the number of people aged 65 or over to the number of people aged 15-64), the national average in 1999 was $11.15 \%$ (9.3\% in 1994) (State Statistical Bureau, 2000: 102). The ratio is expected to increase to $18.1 \%$ by 2020 and 35.3\% by 2050 (Wang, 2001: 472) (see Table $\mathrm{X})$.

\section{Table 6 in about here}

Life expectancy of the Chinese people now reaches 71 years (69 years for men and 73 years for women) (China Daily, April 1, 2001). The annual rate of the increase of the aging population aged over 60 years old averaged at 3\%, which is more than three times the average rate of natural increase in the national population. For those aged over 80 years old, reaching 11 million in 2000, the rate averaged at 5.4\% (China Daily, March 1, 2001). The proportion of the aging population (people aged 65 or over) will reach $9 \%$ by 2010, and further to $21 \%$ by 2050 (Zhang, 2000: 17). (See Table 6.) Being one of the fastest aging societies in the world, China has to face all the social and economic issues of elderly care that are found in developed countries. Yet, its economy is still that of a developing country.

Facing an emerging market economy, both the pension system and formal social services for older people are largely inadequate. For major source of income support, a survey showed that some $71.4 \%$ of the older people had to rely on their children for support, and only $16.9 \%$ received pensions (Zhang, 2000: 6). In the rural areas, peasants in reality have no retirement age. Yet demographic and social changes are affecting the capacity and willingness of the family to provide care for the elderly. In 2000 the majority of the families were nuclear families (families 
with one to four persons); the average household size was 3.44 persons (2.88 persons in Shanghai), down from 4.4 persons in 1982 (People’s Daily, March 27, 2001). Smaller family size means that there are fewer potential caregivers. Furthermore, the number of divorces granted in 2000 reached 1.2 million, which is three times the number in 1981 (Ministry of Civil Affairs, www.mca.gov.cn). In addition, women, who are usually primary caregivers in the family, have been encouraged to actively participate in the workforce. Some $46.7 \%$ of the working population was female, and the rate of women's participation in the labor force reached almost $90 \%$ for those aged between 20 and 44, rather similar to that of their male counterparts (People’s Daily, October 8, 2000). Under the Household Registration system before 1978, it was difficult for people to move from place to place to seek jobs. With the relaxation of the restriction on peasants moving into cities and towns, and urban workers in the western and central provinces seeking jobs in coastal provinces, rural-urban and city-city migration has become more common. In fact, the government intends to grant permanent urban residential status to those migrant workers who have a stable job and source of income, and a permanent address (People's Daily, August 28, 2001). As more rural young people, particularly men, go to the cities for jobs, aged parents risk being 'abandoned.' Some migrants may still maintain responsibility for elder care through sending home remittances; others just disappear (Leung, 1997).

Today's older people were born in or before the 1930s, and married in the 1950s, the period when there was a baby boom. Therefore, they have, on average, three to four children (3.5 in cities and 3.7 in villages) to share the responsibility of care (China Research Center on Aging, 1994: 8). However, when their children who married and gave birth to children in the mid-1970s and the early 1980s become older persons early in the $21^{\text {st }}$ century, they will probably have only one child to look after them. This is one of the inevitable and daunting consequences of the one-child policy implemented in 1980. The phenomenon is described as '4-2-1': that is the responsibility of caring for the two parents and the four grandparents will rest 
on the sole grown up child.

In summary, China is facing a number of challenges to the development of an effective social security system, including a rapidly aging population, liberalized economic structure, reform of SOEs, continuous high demands for jobs in the coming years, uneven regional development, and eroding family capacities.

\section{The Iron Rice Bowl}

Under the centrally-planned economy modeled on the Soviet Union, the system of public ownership, full and life-long employment, job creation and assignment, and restricted labor mobility established by Mao Zedong was regarded as a superior feature of socialism (Walder, 1986; Leung \& Nann, 1995; Shaw, 1996; Lu \& Perry, 1997). Since social security was employment-centered, each work unit functioned as a self-sufficient 'welfare society' within which an individual received employment and income protection, and enjoyed heavily subsidized benefits and services such as housing, food, and education. He or she could also obtain social security benefits for sickness, maternity, work injury, invalidity, death, and old age. Currently, one-third of the schools and $40 \%$ of the hospitals in China are operated by SOEs (Chi, 2000). The socialist ideology rejected the existence of unemployment. There were only 'people waiting for employment' - waiting to be assigned jobs. Through the policy of full-employment, the phenomenon of underemployment was widespread, commonly described in the saying of 'jobs for three persons were shared by five persons.'

Based on distribution decisions made by the administration, a basic, egalitarian security network - the so-called 'iron rice bowl' with 'high employment, high welfare and low wage' was established. While there was no legal entitlement to welfare, the moral obligations and the patron-client relationship between employees and work units ensured paternal protection for 
members in times of difficulty. Up to now, there is still no legislation regulating social security arrangements. All policy documents have been made by the State Council in the forms of regulations and notices. Under such a system, the Chinese people learned to be submissive to, dependent on, and compliant with the benevolent rule of the Communist Party, in return for a protected livelihood with job security and the guarantee of a basic standard of living. To the Chinese Communist Party, this welfare system was a political asset that ensured social stability and legitimacy.

The traditional social security system, which remained largely unchanged before 1980, has the following features:

- The system was solely financed from the operational expenses of each work unit rather than by taxation and employee contribution. Being appendages of the state, work units were not responsible for their profits and losses. Therefore, it was in fact the state that was ultimately financially responsible for the work unit-based system.

- The system basically covered most of the urban employees, since most of the urban workforce was employed in the state sector.

- With life-long employment, it was considered not necessary to cater to the needs of the unemployed.

- Pension benefits were calculated based on a worker's earning prior to retirement and the number of years of working experience. The replacement ratio could reach $80 \%$ of the wage before retirement.

- The operation of the system rest with the trade unions, and the system was largely in disarray during the Cultural Revolution.

From the start of the 1980s, the 'iron rice bowl,' which involved 'everyone eating from the same big pot,' began to be regarded as impeding economic efficiency and productivity by acting as a disincentive. The government was aware that a re-structuring of the social security system would be an indispensable part of the whole process of market-oriented economic reform. 
Economic reforms focused on the gradual liberalization of the economic structure and increases in the production and management autonomy of SOEs. The introduction of the taxation system provided an incentive for SOEs to make a profit and enhance efficiency. In terms of employment, steps were also taken to erode the traditional concept of life-long employment or job security through the introduction in 1986 of contract work, dismissal procedures, bankruptcy law, and unemployment insurance. The traditional job assignment system was gradually replaced by the use of the labor market by both employers and job-seekers. As a result, workers became liable to redundancy as a result of dismissal, bankruptcy, or termination of contract. In addition, the egalitarian wage system was dismantled to provide incentives for improved performance.

With the growing autonomy of SOEs in the context of the market reform, they had to shoulder more and more of the social security expenses themselves. In principle, the government would no longer be responsible for any pension deficits. Since there was no mechanism for the sharing of risk between enterprises with an aging workforce and those that employed a higher ratio of young people, the social security costs of some SOEs could extremely heavy. As the population aged, the system could not cope with rising demand. In fact, the number of retirees soared from only 3 million in 1978 to 16.4 million in 1985, 23 million in 1990, 30.9 million in 1995, and 37.2 million in 1999. Pension payments of enterprises increased from only 5 billion yuan in 1980 to 39.6 billion yuan in 1990 and 242 billion yuan in 1999 . The average annual increase rate was $23 \%$ in the 1980 s, $27 \%$ in the early 1990 s, and declined to 16.7\% between 1996 and 1999 (Table 7).

\section{Table 7 in about here}

The system covered only employees of the SOEs. With the emergence of a more pluralistic economy and employment structure, more urban employees had been left outside this traditional social security network. Furthermore, the non-transferability of a work-unit-based 
social security system did not encourage labor mobility, a prerequisite for a market economy.

\section{Pension reforms}

With the initial experiments in several cities in the early 1980s, all cities were encouraged to set up pooled funds for pensions in 1985, so that enterprises with different numbers of retirees could share their costs. Furthermore, under the new contract workers' scheme (1986), both enterprises and contract employees had to contribute to a funding pool. Since then, 13 pooled funds were established at the provincial level and 11 were organized along different national trade sectors (e.g., civil aviation, railways, banking, electric power, coal mining, and postal service), while the rest were at the city level. Working on a pay-as-you-go basis, participating work units paid contributions to the fund at a defined rate, with retirees drawing out their benefits from the same source. The rate of contribution for each work unit was primarily based on the amount of pension payment made each year, with a small accumulation normally being permitted. The funds were managed by the local labor bureaux rather than by the employing enterprises. Thereafter, retirees, in theory, would receive their monthly benefits directly from local banks or post offices rather than from their previous employers.

Incrementally, the reform in the 1980s focused on promoting the independence and autonomy of SOEs and attempted to share welfare costs. Basically, the benefits of the employees had not been affected. The establishment of pension funds was in fact aimed to transfer the management responsibility from enterprises to the local governments. Still, operating on a pay-as-you-go system, the funds were not able to meet future liabilities. Because of the growing number of retirees, even with the initiation of pooled funds, contribution to pension pools by SOEs showed no sign of decrease (Table 7).

In response to the emergent pluralistic economy, cities focused on the formation of different pooled funds that would cater for the needs of the emerging diversified employment and economic structure. In this way, a pluralistic pension system was established within which 
different funding pools, targeting different types of employees, would have different management organizations, contribution rates, payment standards, and pension benefits. In general, pooled funds can be managed by the labor departments (for employees in SOEs), the personnel departments (for employees in government offices), the insurance companies (employees in COEs), and the civil affairs departments (for employees in township enterprises). Also, a single enterprise had to participate in different pension pools for different types of employees. For example, Guangzhou city had six separate pension pools for different types of employees and enterprises: contract workers in SOEs (1983); permanent workers in SOEs (1985); workers in labor service companies (1986); employees in city-level COEs (1988); temporary workers (1989); and employees in district/street office COEs (1992). In addition, large national SOEs, such as the railways, banking, telecommunications, and water conservancy, had their own pension pools. The segmented structure of the initial pension system, mainly because of the incremental reform approach, led to difficulties with subsequent unification. Noteworthy, too, is the fact that reforms were largely centered on employees in SOEs. Migrant workers and employees in joint ventures and the private sector were not included.

The State Council enacted the Decisions on the Reform of the Retirement Insurance System of Employees in Enterprises in 1991. The Decisions called for the establishment of a multi-layered pension system based on pooled funds and individual savings. Individual employees were required to contribute to these pooled funds. The Decision of the Chinese Communist Party’s Central Committee on Some Issues Concerning the Establishment of a Socialist Market Economic Structure adopted in the $3^{\text {rd }}$ plenary session of the $14^{\text {th }}$ Central Committee in 1993 stated:

The establishment of a multi-layered social security system is of great importance to the deepening of the reform of enterprises and institutions, maintaining social stability and the 
smooth establishment of a socialist market economic structure. We should unify social security policies and legalize their management. The level of social security should suit the development of China's social productive forces and acceptability to all concerned.

Mutual help in society should be encouraged. Commercial insurance will be developed as a supplement to social insurance. (Lieberthal, 1995: 430-31)

In short, recommended changes in the early 1990s included:

a) An intention to extend the pension scheme to cover all types of economic sectors and employees.

b) The requirement of an employee contribution, which was initially limited to $3 \%$ of wages.

c) The establishment of a multi-layered pension system at the provincial level, consisting of the basic benefits and supplementary benefits: The basic benefits were covered by the compulsory contributions from enterprises and employees, while the supplementary benefits could be formed by optional contributions from employers and employees. The basic part was calculated on the basis of a defined percentage (15-25\%), depending on seniority of the local average wage. Enterprises with profits and employees with the financial capacity could put up more funds to the supplementary benefits as individual saving accounts. As such, there was an intention to move the pooled funds toward a fund with partial accumulation.

The Notice Regarding the Deepening of the Reform of the Retirement Insurance System of Employees in Enterprise (1995) proposed the integration of the unified fund and individual accounts. The establishment of individual accounts would intend to, on the one hand, expand the funding source and reduce employers' contribution, and on the other, provide incentives for employees to contribute. More importantly, the establishment of individual accounts was 
intended to move the formerly pay-as-you-go system toward a partially accumulation-based pension system.

In addition, the Notice proposed two operational models of mixing unified funds and individual accounts. The basic difference between the two models is the extent of the individual account. The benefits in the first models depended more on individual contributions (larger proportion of the individual accounts), whereas in the second one they depend more on the local wage level (larger proportion of the unified accounts). While individual accounts can encourage individual contributions and fund accumulation, the unified fund can function to pay for existing retirees and those retirees with insufficient years of contribution. Without clear guidelines, however, different provinces and cities could adopt different pension models with different proportions of pooled funds and individual accounts. In so doing, significant regional variations and uneven development existed. For example, the proportion of individual accounts could vary from $3 \%$ to $17 \%$.

In 1997, drawing on the experiences of a number of pilot projects, the government recommended a unified model for pension arrangements. Under this model, the total contribution allocated to the individual accounts would be equal to $11 \%$ of the employee's monthly wages. Individual contributions would increase by $1 \%$ of the individual's wage every two years, from $4 \%$ up to a maximum of $8 \%$. Meanwhile, the work unit's contribution to the individual accounts would decrease gradually to $3 \%$ as the individual contribution increased. The rate of the work unit's contribution to the unified fund was up to the local authority, but the maximum rate was not allowed to exceed $20 \%$ of the total wage bill. Therefore by the year 2005, the total contribution rates will become $28 \%$ of the total wages, including $20 \%$ from enterprises and $8 \%$ from individual employees.

Current retirees would continue to receive benefits from the unified funds, according to the previous standards. The monthly pension benefits of retirees with more than 15 years' service would contain a basic part - equal to $20 \%$ of the local average wage - and an additional 
sum, equal to the accumulated amount in the individual account divided by 120 . (With the life expectancy in China currently at 70 years and the retirement age of male workers at 60 years, a retiree is expected to live on average for 10 years or 120 months.) Those with less than 15 years of working experiences would only receive a lump sum amount from the individual accounts without the basic pension. The employee's or retiree's relatives could also inherit the portion of the account contributed by individual payment upon his or her death (Leung, 1998). It has been estimated that future retirees will receive only $60 \%$ of their working wages, rather than $80 \%$ as before (Song, 2001: 51). In other words, employees are expected to supplement their pension benefits with other types of insurance schemes. In short, the government attempted to unify the contribution, individual account operation methods, and calculation of benefits. In 1998, the State Council issued a notice to require the 11 nationally organized trade sectors to transfer the management of their pension funds to local governments.

In 1999, unified funds covered about 93.2 million employees (up from 52 million in 1990), representing $44.3 \%$ of the urban population in work. Among the covered population, $68 \%$ were from SOEs, 16\% from COEs, and only 9.7\% from the other types of enterprises, namely privately-owned enterprises, foreign-owned enterprises, and the self-employed. Some $97 \%$ of those working in SOEs were covered, but only 54\% from COEs and 32\% from other enterprises (Wu, 2000). In evading making contributions to social security funds, non-state sectors tended to employ temporary staff or under-report the number of employees. In fact, mainly due to the shrinking number of employees in SOE and the resistance from the non-state sectors in joining the unified funds, the number of employees in the unified funds showed a decrease in 1997 and 1998 (Table 6). Only in 1999, with the government effort to extend to other non-state sectors that the number of employees participating in the unified funds showed significant increases. But again, the figure in 2000 showed a reduction.

Historically, because the pension was based on the wage level prior to retirement, there were regulations prescribing the minimum levels. The minimum levels according to the 
Regulations in 1951 and 1953 were 35\% and 60\% of the wages. In 1978, the minimum became the monthly benefit of 25 yuan. With revisions in 1983, 1985, 1988, and 1992, the minimum level was set at 60 yuan per month (Song, 2001: 111). The minimum level is even lower than the social assistance line. Not surprisingly, inadequate pensions have become a major factor contributing to urban poverty.

In September 1998, the premium contribution rate from enterprises was only 88\%, reflecting more resistance from enterprises to contribute to the funds. With poor performance, more SOEs had difficulties in paying wages, not to mention making social insurance contributions. Indeed, the average contribution rate of enterprises is now $23 \%$ of the total wages (Song, 2001: 45). It is common practice for enterprises to 'pay the differences' to the unified fund - to pay net differences between the total pension received and the total amount of required contributions. Even worse, there is a lack of law to enforce contribution from enterprises. To improve the collection of the contribution, the State Council issued the Temporary Regulations on Collecting Social Insurance Contributions in 1999. The Regulations made it an offence to fail to make contributions.

With the establishment of individual accounts, contributions to the unified funds have decreased. Because of the need to pay for the pension benefits of existing retirees, the money in individual accounts of the pension funds has often been used to make current pension payments. Because individual accounts and their investment returns are not separated administratively from the unified funds, they are in reality notional and exist only on paper (World Bank, 1997: 2). In 1999, the unified funds revenues amounted to 196.5 billion yuan and expenditures to 192.5 billion yuan. These were averaged figures only. In fact, many provinces had already shown deficits. Over the years, the fund reserve has accumulated to 73 billion yuan, which is not enough to pay even half the annual pension bill (China Labor and Security News, June 17, 1999: 1). As the government moves into a fully funded scheme, the unified funds have recorded a gap of 35.7 billion yuan in 2000, which can only widen in the coming decades. In fact, 
estimates of China's pension deficit vary widely. The World Bank has put it at about 1,900 billion yuan, while China has suggested 6,700 billion yuan (South China Morning Post, May 25, 2001: 8).

Since property and stock markets in China are still volatile, government regulations now stipulate that $80 \%$ of the accumulated fund should be invested in government bonds, with the rest to be deposited in banks. Although this arrangement helps to minimize the risk of mis-investment and corruption, it can hardly protect the fund against losses due to inflation. Even so, in 1998 state auditors discovered that about 10 billion yuan in the pension funds had been misappropriated (Wu, 2000).

Despite these reform initiatives, the social security system continues to suffer from problems of narrow coverage, high and uneven employer responsibilities, poor management and investment of funds, and low transferability. Moreover, the government has had to intervene from time to time to ensure that retirees and the unemployed receive their benefits on time. In 2000, the government tried to clear up the pension arrears by making payments of over 17 billion yuan (People's Daily, August 21, 2000). Despite reports of increasing coverage and the enactment of the 'Temporary Regulations on Collecting Social Security Insurance Contribution' by the State Council in 1999, the problem of collecting social security contributions from enterprises, especially small businesses, self-employed entrepreneurs, and ailing SOEs, remains critical (People’s Daily, September 24, 2001). According to the figures produced by the Ministry of Labor and Social Security, some provinces, such as Heilungjiang, Jinin, Wunan, and Hainan, despite being subsidized by the central government, were still unable to pay pensions on time. The Ministry even publicly named 20 SOEs with pension arrears amounting to over 10 million yuan each.

Unless more drastic measures are adopted to unify the system, it is highly unlikely that it will be able to cope with the future liabilities implied by the rising number of retirees. These measures might include extension of coverage, diversification of funding sources, and 
improved fund management (People's Daily, August 21, 2000; September 24, 2001). It is estimated that the government will have to sell its state-owned assets over time to fund social security deficits of about 500 billion yuan (South China Morning Post, March 10, 2001: 9).

In 2000, the State Council set up a National Social Security Foundation. Funded by central government, the Foundation would subsidize local authorities that were facing difficulties in making payments to the laid-off and the retired (People's Daily, September 25, 2000). In July 2001 in Liaoning province, the Ministry of Labor and Social Security announced the launching of a three-year experiment on the reform of the social security system. Liaoning was chosen mainly because of its high concentration of SOEs and large number of laid-off and retired persons. The reforms focused on the establishment of an independently managed social security fund at the provincial level, with diversified funding sources and socialized management (People's Daily, July 9, 2001). Here in Liaoning, the contribution rate of the individual accounts will be limited to a maximum of $8 \%$ of the wage received, instead of $11 \%$ which will be comprised mainly employee contribution only (the current contribution rate is $5 \%$ ). The individual accounts will be administratively separated from the unified funds. To compensate for the reduction of the proportion of the individual accounts, the benefit level of retirees would be adjusted, depending on the number of years of contribution a worker can get.

\section{Programs for the unemployed}

Through the system of public ownership, full and life-long employment, job creation through administrative procedures, job assignment and restricted labor mobility, the government was effective in keeping unemployment under control. As such, employment assistance was considered unnecessary (Yuan \& Feng, 1998: chapter 1). With the reforms of the SOEs and the gradual introduction of a labor market in the early 1980s, layoffs became possible.

Because of the narrow coverage, the 'Waiting for Employment Insurance Scheme’ set up 
in 1986 was under-utilized in the late 1980s. The scheme catered only to those employees in SOEs declaring bankruptcy, with their employment contracts terminated and being dismissed by their SOE employer. Initially, the unemployment benefits were tied to the wage level. As unemployment rose in the early 1990s, they became a more prominent means of providing assistance to the unemployed. Those receiving assistance from the schemes were mainly workers whose contracts had been terminated and laid-off employees who had spent two years in the re-employment service centers but had still been unable to find a job. The schemes offered a basic living allowance to the unemployed for a maximum period of two years, depending on length of service.

According to the revised regulations in 1993, the benefit level should lie between $120-150 \%$ of the local poverty line, but in some places it is actually $70-80 \%$ of the local minimum wage. In other words, the benefit level is close to the local poverty line. In addition, the 1993 regulations had extended the coverage of seven categories of the unemployed, as compared with only four categories in the 1986 regulations.

Traditionally, the scheme was financed solely by drawing $1 \%$ of the total payroll of the participating enterprises. Since 1998, the percentage has been 3\%, with 1\% coming from the employees. The 1986 and 1993 regulations on the unemployment insurance limited the scheme largely to SOE employees. In 1999, the Regulations on Unemployment Insurance (the term of unemployment was officially used to replace 'waiting for employment' in 1994) extended the coverage to all types of employees and economic sectors. In terms of the benefit level, the 1999 regulations only prescribed it to be between the local minimum wage and social assistance line.

In 1999, 96.7 million employees participated in the scheme, which represented about $46.8 \%$ of the urban workforce. Only $43 \%$ of the funds were allocated for unemployment benefits. The rest was for providing re-training courses and supporting re-employment service centers. The number of unemployment insurance recipients declined from 3.3 million in 1996 to only 1.1 million in 1999. In relation to the 5.8 million registered unemployed, the coverage of 
the scheme is limited. From the early 1990s onwards, SOEs have gradually been allowed to make their employees redundant. People laid-off in this way, known as 'xiagang employees' (XG employees) or 'off post' employees, had not been counted as the unemployed before because they still maintained labor relationships with their employers (Wu, 2000). This is why the unemployment rate stayed at about 3\% during the 1990s. If the number of $X G$ employees is included, the unemployment rate in 1999 reached 8.7\% (Table 5). The number of $X G$ employees has increased from 3 million in 1993 to 11 million in 1999. In 1997, the $15^{\text {th }}$ National Congress of the Communist Party of China set a three-year objective for reform of the SOEs: most large and medium-sized SOEs were to turn around their loss-making operations through reform, reorganization, association, improved management, and the establishment of a modern enterprise system. Traditionally ailing industries such as textiles, machinery, metallurgy, petrochemicals, building materials, tobacco, nonferrous metal, electronics, and pharmaceuticals consequently engaged in downsizing, bankruptcy, and merger. As a result, layoffs become more widespread (Beijing Review, 5, 2001).

Some 70\% of them were from SOEs (State Statistical Bureau, 2001: 48). In addition, they tend to be middle-aged, poor in health, female and low-skilled. In the beginning, $X G$ employees received living allowances from their employers. Since 1995, however, a number of re-employment service centers have been set up to provide living allowances, re-training, and job referrals for laid-off employees. The State Council issued the 'The Supplementary Notice Concerning the Issues of Implementing Mergers of SOEs and Re-employment Projects in Selected Cities' in 1997. The Notice encouraged the establishment of re-employment service centers in selected industrial sectors, enterprises, and local districts where there was a high concentration of $X G$ employees. Enterprises that had had more than 5\% of their staff classified as surplus workers, and those in the process of merger or bankruptcy, were required to establish such centers. Enterprises, the unemployment insurance fund, and local governments have financed the re-employment service centers. In reality, however, it is the local governments that 
have often had to shoulder the responsibility for supporting these centers.

According to the 'Notice Concerning the Problems of Strengthening the Management of $X G$ employees and the Establishment of Re-employment Service Centers’ published by the Ministry of Labor and Social Security in 1998, XG employees entering the service centers have to sign a three-year agreement specifying a set of mutual obligations. After signing the agreement, the $X G$ employee was issued with a certificate that enabled him or her to receive an integrated package of services, namely financial support, re-training, and job referrals. If someone refused to sigh the agreement or enter the center, their relationship with their employer would be terminated immediately. After three years, if the employee still fails to find a job, the labor relationship between the employee and the employer will be terminated. Becoming formally unemployed, the person has to seek assistance from unemployment insurance. In theory, an unemployed person can receive support for a maximum of five years (three years with the re-employment service center and two years with the unemployment insurance scheme) before turning to the social assistance program for assistance. However, it is common for $X G$ employees to have informal employment (hidden employment) and at the same time receive assistance from the centers. Besides support from the reemployment service centers, $X G$ employees can receive a variety of advantages, including priority in employment, fee exemption, and loans to initiate self-employment. Also, employers can receive subsidies or tax reductions by employing $X G$ employees. In addition, many $X G$ employees have by special arrangement received service jobs in the neighborhoods.

A summary released by the Ministry of Labor and Social Security, covering the period 1998 to 2000, indicated that there were 23 million XG employees in re-employment service centers, including 5 million drawn from 1,800 enterprises that had declared bankruptcy. Ninety-five percent of these employees had received basic livelihood protection and 65\% subsequently re-entered employment (People’s Daily, March 19, 2001). The phenomenon of $X G$ employees reflected the traditional social contract between SOEs and employees to provide 
life-long job protection.

In 2000, the government announced the gradual closure of these centers, meaning that laid-off employees will now have to seek assistance directly from the unemployment insurance scheme (People's Daily, March 19, 2001). However, the accumulated fund in the unemployment insurance is evidently not sufficient to support the livelihood of all the unemployed, including the $X G$ employees.

\section{Urban-based social assistance program}

Article 45 of the Chinese Constitution recognizes the right of the Chinese people to state assistance to maintain their basic standard of living. However, for decades China had operated only a limited relief program in cities, catering mainly to disabled veterans and the 'three nos'those with no source of income, no capacity to work, and no family support. In the case of the 'three nos,' some of these would be received into institutional care, such as homes for the aged and orphanages. In addition, the program also catered to aged workers forced to take early retirement during the period of economic adjustment in the early 1960s, for victims of political movements, and for elderly overseas Chinese now living in China. In 1992, only 190,000 people in the whole country received assistance, and the per capita benefit was only 38 yuan per month (Tang, 2001).

With rising unemployment, more employees were unable to receive their pensions and wages, particularly under rampant inflation in the early 1990s, and urban poverty has emerged as an urgent concern. Conservative estimates put the current number of people living in poverty in China at 14 million. Some $85 \%$ of the urban poor live in economically backward cities in the central and western regions (Beijing Review, May 19-25, 1997). A survey by the State Statistical Bureau in 1999 showed that some 71\% of poverty-stricken persons were $X G$ employees, unemployed people, and retirees with inadequate pensions (China Civil Affairs 8, 2001: 5). To establish a last-resort welfare safety net in the cities, the government re-structured the 
traditional social assistance program in 1993, with the aim of extending their coverage, raising the level of benefits, and securing financial commitments from the local governments. In the new program, the targets include:

- Traditional recipients of social assistance, the 'three nos';

- Families with financial difficulties due to unemployment;

- Unemployed people not eligible for unemployment benefits or with their time-limited unemployment benefits terminated; and

- Pensioners with inadequate income.

Known as the 'Minimum Living Standard Guarantee System,' the means-tested program provides assistance to persons with urban household registration status (around 31\% of the national population). The assistance line is calculated according to the minimum standard of living, often based on expenditure surveys of low-income households and the financial capacity of the local authority. At a subsistence level, the assistance would merely cover basic food and clothing costs, while taking into account fuel, rental, medical care, and tuition expenses (Leung \& Wong, 1999). In some cities, special allowances are provided for widows and orphans. The rates have been revised according to inflation rates. The assistance rate in Shanghai has been increased gradually from 120 yuan per person per month in 1993 to 280 yuan in 2000. In 2001, the highest levels of assistance are found in coastal cities and the lowest in cities in the western provinces.

In Shanghai, financial assistance is mixed with in-kind assistance. Recipients would have vouchers to obtain grain, edible oil, and fuel from the neighborhood shops. In the beginning years, if the applicant or his/her family member is an employee of a SOE, then the enterprise should be responsible for paying the benefits to the eligible applicant. The program, managed by the local civil affairs departments, only served those not working in SOEs, or those with their enterprises declared bankrupt. This was under the policy of 'one should take care of one's own baby.' Later, with the policy to further reduce welfare responsibilities of SOEs, the 
responsibility for supporting the low-income urban residents has come to rest on the civil affairs departments.

Being community-based in operation, applicants can make applications to the local street office, a neighborhood-based agency of the district People’s Government. The street office cadres carry out investigations, make recommendations for assistance, deliver benefits, keep records, and periodically review the situation of recipients. With the funds allocated from city and district governments, the street office is responsible for delivering the payments to the recipients. Yet there are different patterns of cost-sharing between the city and district governments. For example, the proportion pertaining respectively to the city and district governments of Dailin city is 7:3, while in Qingdao city the proportion is the reverse. In Wuhan city, the responsibility is shared equally between the city and the district government. In Guangzhou, it is the district government that is solely responsible for financing the program.

The State Council recommended in 1997 that the program be implemented in all cities by 1999. Some cities have extended coverage to persons living in nearby villages that fall within their administrations, but their assistance levels would be different. The number of recipients has soared rapidly, from only 2 million people in 1997 (average monthly allowance of 48 yuan per person) to 4.16 million people in early 2001 (average monthly allowance of 60 yuan per person) (China Internet Information Center, www.China.org.cn, August 14, 2001). However, estimates based on the local assistance lines showed that the number of people eligible for assistance reached 14.8 million. Therefore the program now only caters to about one-third of the poverty-stricken population. Among the recipients, about $80 \%$ were unemployed persons, layoffs, and retirees. In 1998, to celebrate the $50^{\text {th }}$ anniversary of the People's Republic of China, the benefit levels of all cities were raised by $30 \%$. Some $80 \%$ of the funds for the increases were financed by the central government. Economically prosperous coastal cities have to cover the increases themselves. As a result of the increase, more people, in principle, will be eligible for assistance. The 1999 Regulations on the Minimum Living Standard 
Guarantee system prescribed all city government to include the social assistance expenses in the city budgets.

In short, the scheme provides nationwide basic protection to poverty-stricken urban residents. It attempts to fill the gaps between the inadequacy of social insurance programs and the eroding ability of families to provide support. The most urgent concern is the guarantee of funding from the city authorities to continue support for the program. In particular, cities in the hinterland will find the financial responsibility too heavy.

\section{Issues and prospects}

In the social security reforms, the Chinese government made efforts to reduce the financial responsibility of the SOEs for welfare. It is expected that local governments should share more of the responsibility. The $10^{\text {th }}$ Five Year Plan on Economic and Social Development (2001-2005) stated that a viable social security system is the foundation for the development of the socialist market economy. Specifically, the state should ensure that basic living allowances for laid-off workers from SOEs and basic pensions for retirees are paid in full and on time (People’s Daily, September 25, 1999; China Daily, March 6, 2001). Between 2001 and 2005, the government pledged to establish a social security system with the following characteristics: more extensive coverage, independence from enterprises and government offices, diversified sources of revenue, a formalized system, and socialized management. It was also stated that individual accounts should be separated from unified funds so as to allow genuine accumulation. Likewise, the coverage of the unemployment insurance scheme was to be extended to other economic sectors, and people laid-off from SOEs were to receive assistance from the scheme directly. Above all, the plan stated that the coverage of the Minimum Living Standard Guarantee System would be further extended to cover all poverty-stricken families, and the level of benefits would be raised gradually according to the level of economic development of the city and the financial capacity of the local government authorities (China 
Civil Affairs 8: 2001: 7).

Despite all the pledges, the current system has shown shortcomings in the following areas:

- The primary source of income for social security expenses still comes from enterprises. Financial responsibilities of enterprises show little sign of reduction;

- Since individual accounts are notional, it is basically a pay-as-you-go system. The reform toward the establishment of partially funded system has failed.

- The coverage of the system is narrow (retirement, unemployment, and social assistance), and the extension of the system to cover the non-state sector has met with resistance.

- Both the existing pension system and the unemployment insurance scheme cannot cope with the future mounting demands.

Facing these problems, China is still searching for solutions. In the retirement insurance proposal, suggestions included (Wang, 2001; Chen, 2001):

- Abolish the individual accounts, and returning to the PAYO system;

- Assuming the responsibility for supporting existing retirees by local governments;

- Reducing pension benefits through a more rational method of benefit calculation;

- Extending the retirement age; and

- Establishing a social security tax.

Social security reforms in China have been incremental, the emerging system is largely decentralized and segmented. Access to benefits is primarily differentiated among occupational groups, economic sectors, geographical regions, and residential status. Meanwhile, in the absence of a compensatory social and economic policy, economic globalization has inevitably exacerbated the tendency toward inequality in the distribution of income (Khan \& Riskin, 2001: 7). The Chinese social security system has tended to accentuate existing income inequalities. In 
2000, the Gini coefficient reached 0.397 (China Civil Affairs, 8, 2001: 6). Growing income disparities threaten social stability. ${ }^{1}$ The dilemma facing the Chinese government after its entry into the WTO is to balance between the demands to contain the social security expenses of enterprises and the need to mitigate social tensions instigated by rising unemployment and widening income disparities (Perry \& Sheldon, 2000). Not surprisingly, social security reforms in China have been incremental and cautious.

With the entry of China into the WTO, all provinces and cities have had to cope with thriving competition for overseas investment. Rising labor costs and social security expenses may in many ways be considered deterrents to foreign direct investments. In addition, both SOEs and the agricultural sector will bear the brunt of the further opening of the Chinese market. Social security responsibilities for SOEs and large COEs are still heavy, while private and joint venture businesses can maintain a relatively low welfare commitment.

White (1998: 193) has precisely summarized the direction of social security reforms in China:

... the resulting welfare structure is likely to be heavily residualist in the sphere of social assistance and Bismarckian in terms of social insurance, with relatively privileged sectors and relatively excluded sectors. 


\section{References}

Beijing Review (1997). Beijing, May 19-25.

Beijing Review (2001). Vol. 38. Beijing.

Chen JG (2001). China Social Security System Development Report (1997-2001). Beijing, Social Science Publishers.

Chi AM (2000). An exploration into the welfare policy reform of state-owned enterprises. Journal of the China Mining University 1: 25-28.

China Civil Affairs (2001). Vol. 8: 5, 6, 18-21. Ministry of Civil Affairs.

China Daily (2001). Beijing, March 1, March 6, April 1, August 13.

China Internet Information Center (2001). www.China.org.cn.

China Labor and Security News (1999). June 17, p. 1. Ministry of Labor and Social Security.

China Research Center on Aging (1994). A Data Compilation of the Survey on China's Support Systems for the Elderly. Beijing, Hualing Press.

The Economist (2001). London, August 11, p. 23.

Khan AR, Riskin C (2001). Inequality and Poverty in China in the Age of Globalization. New York, Oxford University Press.

Leung J, Nann R (1995). Authority and Benevolence: Social Welfare in China. Hong Kong, Chinese University Press.

Leung J (1997). Family support for the elderly in China: issues and challenges. Journal of Aging and Social Policy 9(3): 7-101.

Leung L (1998). Social security reforms: a long and winding road. In: Cheng J, ed. China Review 1998. Hong Kong, Chinese University Press, pp. 480-499.

Leung J, Wong H (1999). The emergence of a community-based social assistance programme in urban China. Social Policy and Administration 33(1): 39-54.

Lieberthal K (1995). Governing China. New York, W. W. Norton.

Lu XB, Perry E, eds. (1997). Danwei: The Changing Workplace in Historical and Comparative Perspective. Armonk, NY, M. E. Sharpe.

Ministry of Civil Affairs. www.mca.gov.cn.

Ministry of Civil Affairs (2001). China Civil Affairs Statistical Yearbook 2001. Beijing, China Statistical Press.

Ministry of Labor and Social Security (1999). Overall development direction for labor and social security tasks in 1998-2002. China Labor Human Resources Development 7: 4-7.

People's Daily (1999). Beijing, September 25.

People’s Daily (2000). Beijing, August 21, September 25, October 8, 
People’s Daily (2001). Beijing, March 19, 21, 27, and 29, July 9, August 10 and 21, September 24, October 19, November 7, and December 12.

People's Daily (2002). Beijing, January 1 and 16.

Perry E, Shelden M, eds. (2000). Chinese Society: Change, Conflict, and Resistance. New York, Routledge.

Shaw V (1996). Social Control in China, A Study of Chinese Work Units. Westport, CT, Praeger. Song XW (2001). Report on the Reform and Development of China's Social Security System.

Beijing, People’s University Press.

South China Morning Post (2001). Hong Kong, March 10 and May 25.

State Statistical Bureau (2000). China Statistical Yearbook 2000. Beijing, State Statistical Press. State Statistical Bureau (2001). State Statistical Yearbook 2001. Beijing, State Statistical Press. Tang J (2001). The problem of urban poverty and the social assistance system. Social Security System 7: 30-34.

Walder A (1986). Communist Neo-traditionalism: Work and Authority in China's Industry. Berkeley, University of California Press.

Wang MK (2001). Restructuring China's Social Security System: Funding, Operation and Governance. Beijing, China Development Publisher.

Wang SG, Hu AG (2001). The Chinese Economy in Crisis: State Capacity and Tax Reform. Armonk, NY, M. E. Sharpe.

White G (1998). Social security reforms in China: towards an East Asian model. In: Goodman R, White G, Kwon HJ, eds. The East Asian Welfare Model: Welfare Orientalism and the State. London, Routledge.

World Bank (1997). Old Age Security: Pension Reform in China. Washington, DC, The World Bank.

World Bank (2001). World Development Report 2000-2001. New York, Oxford University Press).

Wu XY (2000). China's social insurance situation and reforms in 1998-1999. In: Ru X, Lu XY, Shan TL, eds. The Analysis and Forecast of Social Situation in China in 1999. Beijing, China Social Science Publishers, 147-64.

Yuan ZG, Feng YZ (1998). The Transformation of the Employment System in China. Taiyuan, Shanxi Economic Publishers.

Zhang WF (2000). The Problems and Responses of Population Aging in China in the First Half of the 21st Century. Beijing, Hauling Publishers. 
